UDK $577.1: 61$

ISSN 1452-8258

J Med Biochem 39: 83-90, 2020

\title{
URINARY NEPHRIN IS EARLIER, MORE SENSITIVE AND SPECIFIC MARKER OF DIABETIC NEPHROPATHY THAN MICROALBUMINURIA
}

\author{
URINARNI NEFRIN JE RANIJI, OSETLIVIJI I SPECIFIČNIJI MARKER DIJABETESNE \\ NEFROPATIJE NEGO MIKROALBUMINURIJA
}

\author{
Irena Kostovska1, Katerina Tosheska Trajkovska1, Sonja Topuzovska1, Svetlana Cekovska1, \\ Goce Spasovski², Ognen Kostovski ${ }^{3}$, Danica Labudovic ${ }^{1}$ \\ ${ }^{1}$ Department of Medical and Experimental Biochemistry, Medical Faculty, Skopje, R. Macedonia \\ ${ }^{2}$ University Department of Nephrology, Medical Faculty, Skopie, R. Macedonia \\ ${ }^{3}$ University Clinic of Abdominal Surgery, Medical Faculty, Skopje, R. Macedonia
}

\section{Summary}

Background: Diabetic nephropathy (DN) is a leading cause of end-stage renal disease. Progressive damage and decline in the number of podocytes often occur in the early stages of DN. Thus, nephrin as a podocyte-specific protein may be regarded as a potential biomarker of early detection of DN. The aim of this study is to determine whether urinary nephrin is an earlier marker in DN than microalbuminuria and to test the significance of urinary nephrin as a marker for early detection of DN.

Methods: Our cross-sectional study included 90 patients with type 2 diabetes mellitus (T2DM), 30 patients with diagnosed DN and 60 patients without diagnosed DN. As a control group, we used 30 healthy subjects. All patients with T2DM were classified into three subgroups according to urinary microalbumin/creatinine ratio (UMCR): normoalbuminuric, microalbuminuric and macroalbuminuric patients. Nephrin in urine was measured by immunoenzyme assay, microalbumin with turbidimetric and creatinine with the photometric method. In blood sera, we measured a few standard biochemical parameters.

Results: Nephrinuria was found to be present in $100 \%$ of patients with T2DM and macroalbuminuria, in $88 \%$ with microalbuminuria, as well as $82 \%$ of patients with T2DM and normoalbuminuria. A concentration of urinary nephrin was significantly increased in all groups of subjects with T2DM compared to the control group $(p<0.05)$.

\section{Kratak sadržaj}

Uvod: Dijabetesna nefropatija (DN) je vodeći uzrok završnog stadijuma bubrežne bolesti. Progresivno oštećenje opadanje broja podocita često se javlja u ranim fazama DN, tako da se nefrin kao specifični protein podocita može smatrati potencijalnim biomarkerom ranog otkrivanja DN Cilj ove studije je da utvrdi da li je urinarni nefrin raniji marker DN u odnosu na mikroalbuminuriju i da testira značaj urinarnog nefrina kao markera za rano otkrivanje DN.

Metode: Naša studija preseka je obuhvatila 90 pacijenata sa dijabetesom tipa 2 (T2DM), 30 bolesnika sa dijagnozom DN i 60 pacijenata bez dijagnoze DN. Za kontrolnu grupu smo koristili 30 zdravih ispitanika. Svi bolesnici sa T2DM klasifikovani su u tri podgrupe prema odnosu urinarnog mikroalbumina/kreatinina (UMCR): normoalbuminurni, mikroalbuminurni i makroalbuminurni pacijenti. Nefrin u urinu je meren imunoenzimskim testom, mikroalbumin uz korišćenje turbidimetrijske i kreatinin koristeći fotometrijsku metodu. U krvnim serumima, merili smo nekoliko standardnih biohemijskih parametara.

Rezultati: Ustanovljeno je da je nefrinurija prisutna u 100\% pacijenata sa T2DM i makroalbuminurijom, u $88 \%$ sa mikroalbuminurijom, kao i $82 \%$ pacijenata sa T2DM i normoalbuminurijom. Koncentracija urinarnog nefrina značajno je povećana u svim grupama ispitanika sa T2DM u poređenju sa kontrolnom grupom ( $p<0,05)$. Nefrinurija je korelirala statistički negativno sa eGFR $(r=-0,54)$. ROC

\footnotetext{
Address for correspondence:

Irena Kostovska

Department of Medical and Experimental Biochemistry,

Medical Faculty, University Ss. Cyril and Methodius, Skopje, R. Macedonia

50 Divizija Street, 1000, Skopje, R. Macedonia

Phone: +389078208990

e-mail: irenakostovska22@yahoo.com
} 
Nephrinuria correlated statistically negative with eGFR $(r=-0.54)$. ROC analysis showed that nephrin has a total predicted probability of $96 \%$ in patients with DN.

Conclusions: Urinary nephrin is earlier, more specific and sensitive marker than microalbumin in early detection of DN.

Keywords: nephrin, microalbumin, diabetic nephropathy

\section{Introduction}

Diabetic nephropathy (DN) is a clinical syndrome characterized by the following: persistent albuminuria ( $>300 \mathrm{mg} / \mathrm{d}$ ) that is confirmed on at least 2 occasions 3-6 months apart, progressive decline in GFR and elevated arterial blood pressure. It is the most common complication in patients with type 2 diabetes mellitus (T2DM). Almost $40 \%$ of diabetic patients develop DN, but the incidence is much larger in new onset cases of T2DM. DN is a leading cause of the end-stage renal disease (ESRD), which require renal replacement therapies, dialysis or transplantation. These therapies have a great economic impact an economic loss to people with diabetes and their families, national economies and health systems through direct medical costs and loss of work and wages (1-4). Thus, early detection of renal involvement in patients with T2DM is important for timely treatment and to slow the disease progression to ESRD. Microalbuminuria was previously considered $\mathrm{s}$ a gold standard in early detection of $\mathrm{DN}$ despite being a non-specific marker, concomitantly present in other pathological conditions such as urinary tract infections, cardiovascular disease, in non-diabetic patients, etc. In addition, the body of evidence indicates a high percentage of patients with T2DM, who have renal involvement despite the absence of microalbuminuria $(5,6)$. Studies have shown a progressive decline in the number of podocytes and disappearance of foot processes which occur in the early stages of DN due to apoptosis or shedding of podocytes. Therefore, urinary podocytes and their specific proteins may be regarded as potential biomarkers of podocyte injury. These facts motivated us to investigate novel biomarkers for early detection of DN. Currently, new and more specific markers for early detection and prediction of DN that appear in the urine before microalbuminuria are being evaluated, and the studies are generally focused on the podocyte-specific protein products because it is difficult to detect urinary podocytes directly $(7-10)$. Recently particular attention has been paid to the role of specific podocyte proteins such as nephrin, podocalyxin, synaptopodin, podocin, mindin, etc., in early detection of DN. Among these new urinary biomarkers, the podocyte protein - nephrin has been evaluated as the most promising one in early detection of DN (11).

Podocytes, visceral epithelial cells, are key structural elements of the glomerular filtration barrier (12). Nephrin is a transmembrane glycoprotein which plays analiza je pokazala da je kod pacijenata sa DN ukupna predviđena verovatnoća nefrina $96 \%$.

Zaključak: Urinarni nefrin je raniji, specifičniji i osjetljiviji marker od mikroalbumina u ranom otkrivanju DN.

Ključne reči: nefrin, mikroalbumin, dijabetesna nefropatija

an essential role in the structure of the filtration diaphragm and provides the ultimate physical barrier for plasma proteins. Decreased number of podocytes at a glomerular level and presence of podocytes in urine - podocyturia were reported in DN (13-15). The loss of podocytes leads to glomerulosclerosis and together with the damage of the podocyte's cytoskeleton and filtration diaphragm lead to proteinuria (16-18). Damage of podocyte cells and their shedding result into the presence of podocyte-specific proteins in urine, such as nephrin, rendering it as an attractive marker for non-invasive early diagnosis or prediction of DN.

Our study aimed to: 1) determine whether urinary nephrin is an earlier marker in DN than microalbuminuria by classification of all diabetic patients into three subgroups according to UMCR and comparison of concentration of urinary nephrin between subgroups of patients and healthy subjects and 2) test the diagnostic significance of nephrinuria in early detection of DN by comparison of concentration of urinary nephrin among selected groups and among classified subgroups of patients and healthy subjects, by correlation among urinary nephrin concentration and eGFR and testing the predicted probability of urinary nephrin in patients with $\mathrm{DN}$.

\section{Materials and Methods}

\section{Subjects}

This cross-sectional study included 90 patients with T2DM. We selected two groups of patients with T2DM: patients with T2DM with diagnosed DN $(n=30)$ and patients with T2DM without diagnosed DN $(n=60)$. Healthy subjects $(n=30)$ were used as a control group. Patients with diagnosed DN were recruited from the University Department of Nephrology at the Medical Faculty in Skopje. Inclusion criteria for patients with nephropathy were the presence of T2DM with clinically diagnosed nephropathy defined by macroalbuminuria or macroalbuminuria and abnormal renal function, represented by an abnormality in serum creatinine and glomerular filtration rate (GFR). We used this group of patients to determine whether urinary nephrin is elevated in all patients with diagnosed DN and to test the diagnostic performance of nephrin in patients with DN. Diabetic patients without DN were recruited from the Primary Health Care Offices. Inclusion criteria for patients with T2DM with- 
out nephropathy were: duration of diabetic disease for no more than 5 years (generally new-onset cases), absence of pregnancy in women and absence of any type of renal disease.

All patients with T2DM were diagnosed in the Centre of Diabetes at the University Department of Endocrinology and Metabolic Diseases.

All subjects with T2DM $(n=90)$ were classified into three subgroups depending on UMCR: patients with normoalbuminuria - UMCR $<30 \mathrm{mg} / \mathrm{g}(\mathrm{n}=56)$, microalbuminuria - UMCR 30-300 mg/g $(n=25)$ and patients with macroalbuminuria - UMCR $>300$ $\mathrm{mg} / \mathrm{g}(\mathrm{n}=9)$. Classification was done according to KDIGO - Kidney Disease: Improving Global Outcomes - the giudelines from 2012 (19).

\section{Samples and methods}

We used the first midstream morning urine and blood sera. Urine $(10 \mathrm{~mL})$ was collected in clean plastic containers, without any preservative. After centrifugation of blood at $3.000 \mathrm{rpm}$ for $10 \mathrm{~min}$, serum was collected in $1.5 \mathrm{~mL}$ Eppendorf tubes. Firstly, a chemical analysis of the fresh urine was done by using urinary dipsticks. Then, microalbumin concentration in urine was measured by a turbidimetric method and creatinine by using the Jaffe reaction on biochemical analyser ChemWell (2910 Awareness Technology, Inc.). The rest of the urine samples after centrifugation were stored at $-80{ }^{\circ} \mathrm{C}$ until quantification of the nephrin.

Microalbumin/creatinine ratio was determined by using the mathematical formula from the assessed concentration of microalbumin and creatinine in urine. The glomerular filtration rate (GFR) was calculated by Cocroft and Gault formula (20).

The concentration of nephrin in urine was determined using commercially available kits (Exocell Inc., Philadelphia, PA). The method is an indirect competitive ELISA with polyclonal antibodies used against nephrin. Antigens - nephrin from a urine sample and immobilized nephrin antigens (at the bottom of polystyrene plates) compete for anti-nephrin rabbit antibodies. Antirabbit HRP (HRP-horseradish peroxidase) conjugate is used for detection of bound antibodies. After rinsing, the remaining concentration of antibody conjugate bound to immobilized nephrin antigens is measured photometrically at $450 \mathrm{~nm}$ wavelength. The colour intensity is inversely proportional to the concentration of nephrin in the urine sample. The concentration of nephrin was read from a standard curve constructed on commercial standards. The results are presented in $\mathrm{ng} / \mathrm{mL}$.

In blood sera, we measured the concentrations of the following parameters: urea, creatinine, glucose, total protein, and albumin. All parameters were measured by photometric method on biochemical analyser ChemWell. Data on age, sex, height, weight, duration of the disease, blood pressure and glycaemic control were collected from the patients' records and completed questionnaires.

All analyses were performed at the Institute of Medical and Experimental Biochemistry, Medical Faculty in Skopje. Informed written consents were obtained from all participants. The study was approved by the Ethical Committee of the Medical Faculty in Skopje, Macedonia.

\section{Statistical analysis}

Statistical analyses were performed by using the Statistical package SPSS and R. We perform statistical analysis by using: Kolmogorov-Smirnov test, MannWhitney $U$ test, ONE-way analysis of variance (ANOVA), Kruskal-Wallis test, Spearmanžs rank-order correlation and binary logistic regression with Receiver Operating Characteristic (ROC) curve. Statistical significance was defined as $p<0.05$.

\section{Results}

\section{Clinical data of subjects}

Clinical characteristics of the subgroups of patients with T2DM and healthy subjects are shown in Table $/$ and $I I$.

The concentration of urinary nephrin in all patients with T2DM and healthy subjects

We performed a comparison of concentration of urinary nephrin between all patients with T2DM and healthy subjects by Mann-Whitney test. The results are shown in Figure 1.

\section{Reference values of urinary nephrin}

Reference values of urinary nephrin were calculated by using the distribution of frequencies of urinary nephrin in healthy subjects. Considering the nonparametric distribution of urinary nephrin in healthy subjects, reference values were calculated by using the interquartile range (IQR) formula: 50 percentiles + (75 percentiles - 25 percentiles 1.5), respectively we calculate $136+119=255 \mathrm{ng} / \mathrm{mL}$ ( 255 $\mathrm{ng} / \mathrm{mL}$ ). Hence, pathological values for urinary nephrin are $255 \mathrm{ng} / \mathrm{mL}$. Data for urinary nephrin in healthy subjects are shown in Table III.

We determined the percentile of subjects with elevated urinary nephrin ( $255 \mathrm{ng} / \mathrm{mL}$ ) in subgroups of subjects according to UMCR, and we found that nephrin was elevated in $100 \%$ of subjects with macroalbuminuria, $88 \%$ of subjects with microalbuminuria and it is particularly high (82\%) in subjects with normoalbuminuria. Only $10 \%$ of healthy subjects have had elevated urinary nephrin. The results are shown in Figure 2. 
Table I Clinical characteristics of subgroups of patients with T2DM classified according to UMCR and healthy subjects.

\begin{tabular}{|c|c|c|c|c|c|}
\hline & Macroalbuminuria & Microalbuminuria & Normoalbuminuria & $\begin{array}{l}\text { Healthy } \\
\text { subjects }\end{array}$ & $\begin{array}{c}\text { Kruskal - } \\
\text { Wallisp-value }\end{array}$ \\
\hline Age (years) & $59.1 \pm 10.6$ & $57.2 \pm 8.2$ & $57.4 \pm 6.9$ & $47.8 \pm 9.3$ & 0.005 \\
\hline $\begin{array}{l}\text { Duration of disease } \\
\text { (years) }\end{array}$ & $13 \pm 6.7$ & $8.5 \pm 6.5$ & $4.8 \pm 4.2$ & / & $<0.05$ \\
\hline $\operatorname{BMI}\left(\mathrm{kg} / \mathrm{m}^{2}\right)$ & $29.5 \pm 5.6$ & $28.8 \pm 3.6$ & $28.7 \pm 4.0$ & $25.6 \pm 3.8$ & $<0.05$ \\
\hline Glucose $(\mathrm{mmol} / \mathrm{L})$ & $9.9 \pm 3.9$ & $8.1 \pm 2.9$ & $6.8 \pm 2.4$ & $4.2 \pm 1.1$ & $<10^{-3}$ \\
\hline UMCR $(\mathrm{mg} / \mathrm{g})$ & $437.8 \pm 170.8$ & $89.6 \pm 57.9$ & $12.1 \pm 6.9$ & $15.1 \pm 15.4$ & $<10^{-3}$ \\
\hline $\operatorname{HbA1c}(\%)$ & $7.9 \pm 0.9$ & $7.4 \pm 1.6$ & $6.9 \pm 1.1$ & $4.7 \pm 0.4$ & 0.025 \\
\hline Total proteins $(\mathrm{g} / \mathrm{L})$ & $72.1 \pm 8.1$ & $64.1 \pm 11.4$ & $62.4 \pm 10.5$ & $73.7 \pm 5.8$ & $<10^{-3}$ \\
\hline Albumin $(\mathrm{g} / \mathrm{L})$ & $39 \pm 4.3$ & $36.2 \pm 9.2$ & $37.5 \pm 6.5$ & $46.4 \pm 2.9$ & $<10^{-3}$ \\
\hline Urea $(\mathrm{mmol} / \mathrm{L})$ & $7.9 \pm 2.1$ & $8.4 \pm 5.4$ & $6.7 \pm 1.9$ & $4.3 \pm 1.1$ & $<10^{-3}$ \\
\hline Creatinine $(\mathrm{mmol} / \mathrm{L})$ & $109.5 \pm 7.5$ & $81.5 \pm 15.1$ & $75.9 \pm 13$ & $75.1 \pm 14.6$ & $<10^{-3}$ \\
\hline $\begin{array}{l}\text { eGFR } \\
\left(\mathrm{ml} \mathrm{min}-11.73 \mathrm{~m}^{-2}\right)\end{array}$ & $48.2 \pm 12.5$ & $65 . \pm 19.6$ & $67.5 \pm 12.5$ & $91.3 \pm 5.9$ & $<10^{-3}$ \\
\hline $\begin{array}{l}\text { Nephrin in urine } \\
(\mathrm{ng} / \mathrm{mL})\end{array}$ & $1086.5 \pm 550$ & $983.3 \pm 1182.5$ & $444.6 \pm 237.6$ & $160.5 \pm 58$ & $<10^{-3}$ \\
\hline
\end{tabular}

Results are shown as mean \pm SD. BMI - body mass index, HbA1c - glycated haemoglobin A1c, eGFR - (estimated Glomerular Filtration Rate).

Table II Clinical characteristics of patients with T2DM with and without diagnosed DN and healthy subjects.

\begin{tabular}{|c|c|c|c|c|}
\hline & $\begin{array}{l}\text { Diabetic patients } \\
\text { with diagnosed } \\
\text { nephropathy }\end{array}$ & $\begin{array}{c}\text { Diabetic patients } \\
\text { without diagnosed } \\
\text { nephropathy }\end{array}$ & $\begin{array}{l}\text { Healthy } \\
\text { subjects }\end{array}$ & $\begin{array}{c}\text { Kruskal -Wallis } \\
\text { p-value }\end{array}$ \\
\hline Age (years) & $55.8 \pm 10.1$ & $57.9 \pm 6.7$ & $47.8 \pm 9.3$ & $<10^{-3}$ \\
\hline Duration of disease (years) & $10.7 \pm 6.9$ & $4.9 \pm 4.5$ & / & $<10^{-3}$ \\
\hline $\mathrm{BMI}\left(\mathrm{kg} / \mathrm{m}^{2}\right)$ & $28.8 \pm 4.2$ & $28.7 \pm 4.1$ & $25.6 \pm 3.8$ & 0.002 \\
\hline Glucose (mmol/L) & $9.3 \pm 3.6$ & $6.8 \pm 2.3$ & $4.2 \pm 1.1$ & $<10^{-3}$ \\
\hline UMCR $(\mathrm{mg} / \mathrm{g})$ & $209.5 \pm 206.1$ & $16.9 \pm 18.9$ & $15.1 \pm 15.4$ & $<10^{-3}$ \\
\hline HbA1c (\%) & $7.7 \pm 1.6$ & $6.9 \pm 1.1$ & $4.7 \pm 0.5$ & 0.020 \\
\hline Total proteins $(\mathrm{g} / \mathrm{L})$ & $69.5 \pm 9.9$ & $61.3 \pm 10.8$ & $73.7 \pm 5.8$ & $<10^{-3}$ \\
\hline Albumin $(\mathrm{g} / \mathrm{L})$ & $38.3 \pm 9.3$ & $36.6 \pm 6.3$ & $46.4 \pm 2.8$ & $<10^{-3}$ \\
\hline Urea (mmol/L ) & $8.3 \pm 5.3$ & $6.7 \pm 2.1$ & $4.3 \pm 1.1$ & $<10^{-3}$ \\
\hline Creatinine $(\mathrm{mmol} / \mathrm{L})$ & $94.1 \pm 18.1$ & $74.9 \pm 12.1$ & $75.1 \pm 14.6$ & $<10^{-3}$ \\
\hline $\begin{array}{l}\text { eGFR } \\
\left(\mathrm{ml} \mathrm{min} \min ^{-1} 1.73 \mathrm{~m}^{-2}\right)\end{array}$ & $61.1 \pm 21.8$ & $67.1 \pm 12.5$ & $91.3 \pm 5.9$ & $<10^{-3}$ \\
\hline Nephrin in urine $(\mathrm{ng} / \mathrm{mL})$ & $1043.3 \pm 889.5$ & $418.7 \pm 233.1$ & $160.5 \pm 58$ & $<10^{-3}$ \\
\hline
\end{tabular}

Results are shown as mean \pm SD. BMI - body mass index, HbA1c - glycated hemoglobin A1c, eGFR - (estimated Glomerular Filtration Rate). 


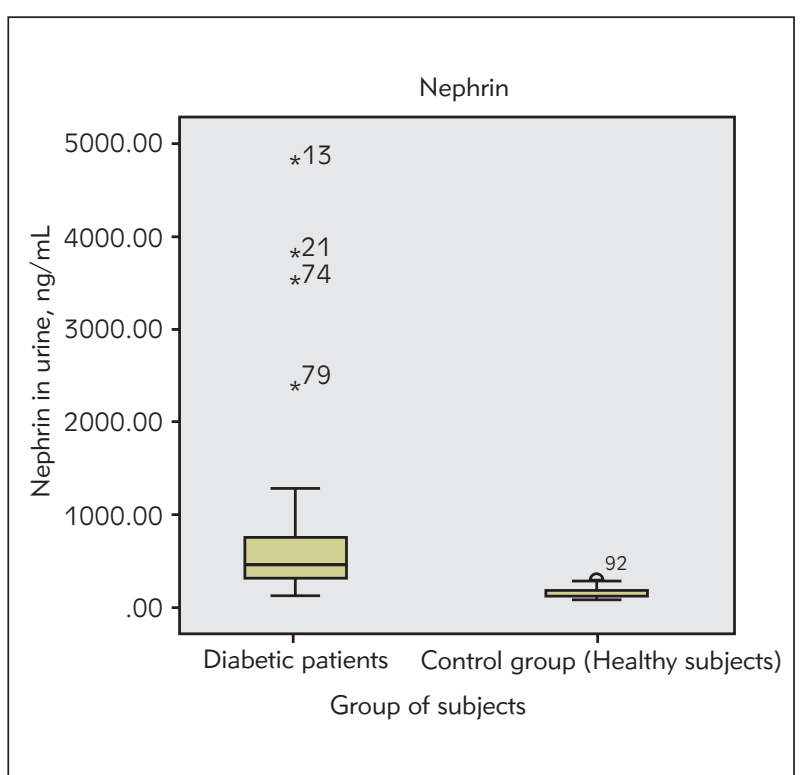

Figure 1 The concentration of urinary nephrin in all patients with T2DM and healthy subjects.

Table III The concentration of urinary nephrin in healthy subjects.

\begin{tabular}{|c|c|c|c|c|c|c|c|c|c|}
\hline \multirow{2}{*}{$\begin{array}{l}\text { Nephrin } \\
\text { (ng/mL) }\end{array}$} & \multirow{2}{*}{$\mathrm{n}$} & & \multirow{2}{*}{ SD } & \multirow{2}{*}{ Min. } & \multirow{2}{*}{ Max. } & \multirow{2}{*}{ Median } & \multicolumn{3}{|c|}{ Percentile } \\
\hline & & & & & & & 25 & 50 & 75 \\
\hline $\begin{array}{l}\text { Healthy } \\
\text { subjects }\end{array}$ & 30 & 160 & 58 & 94 & 315 & 136 & 110 & 136 & 189 \\
\hline
\end{tabular}

The concentration of urinary nephrin in selected groups and classified subgroups of subjects with T2DM

By using Kruskal-Wallis test, we compared the levels of urinary nephrin between the subgroups of subjects classified according to UMCR and healthy subjects. The results show that the elevation of the level of urinary nephrin is statistically significant in all subgroups of subjects with T2DM compared to healthy subjects $(p<0.05)$. Results are shown in Figure 3. We compared the levels of urinary nephrin between the selected groups of subjects with and

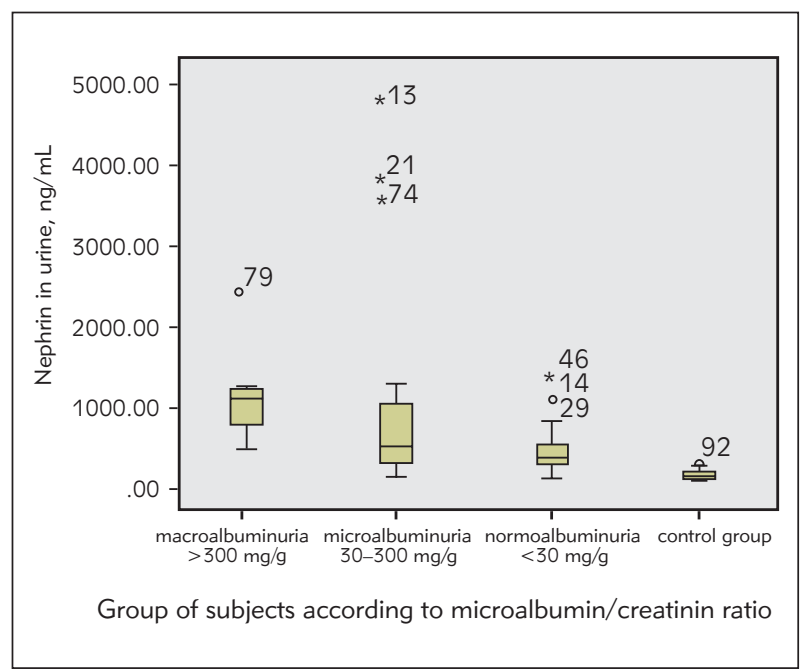

Figure 3 The concentration of urinary nephrin in subgroups of subjects classified according to UMCR.

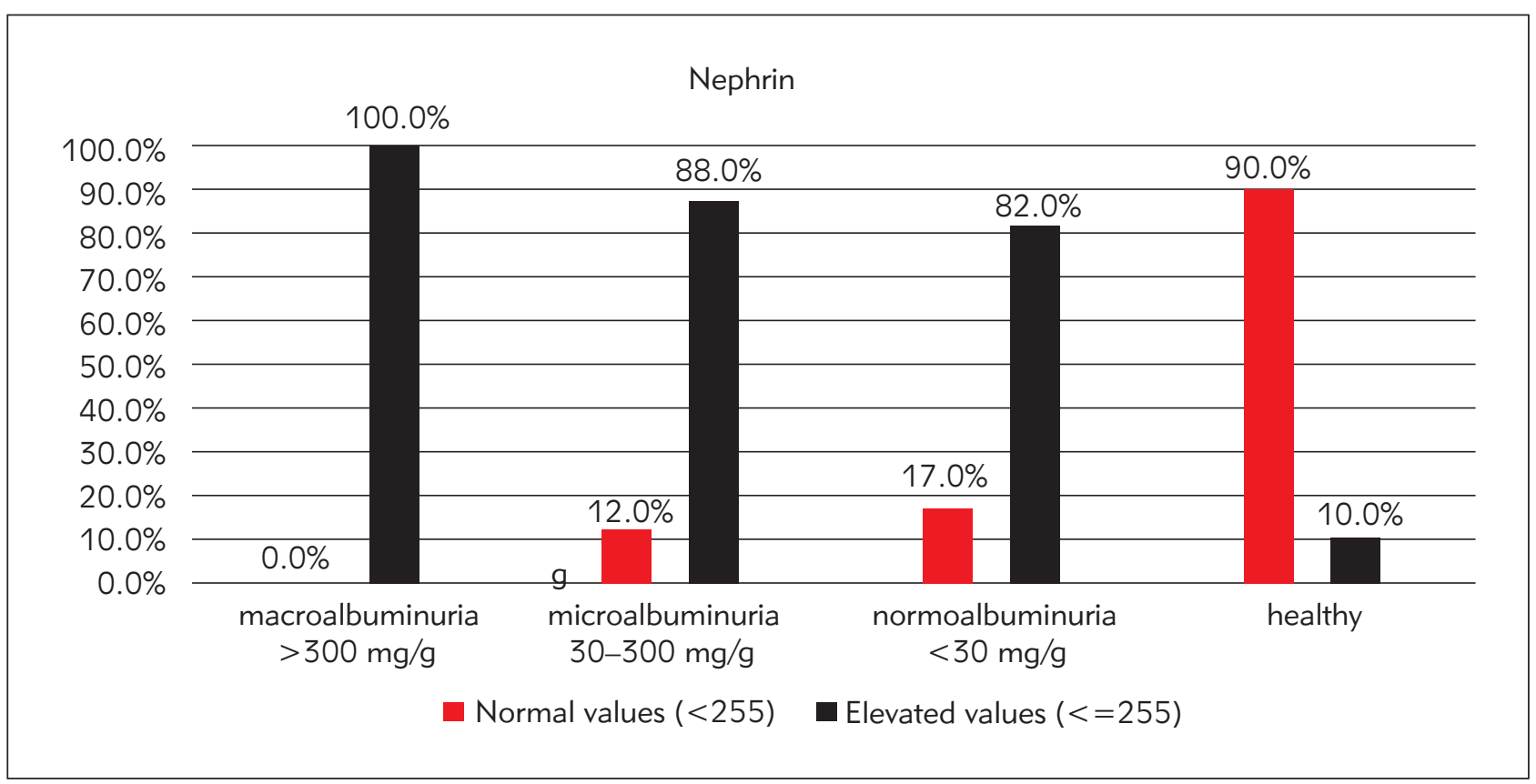

Figure 2 The percentage of subjects with elevated urinary nephrin in subgroups of patients classified according to UMCR. 


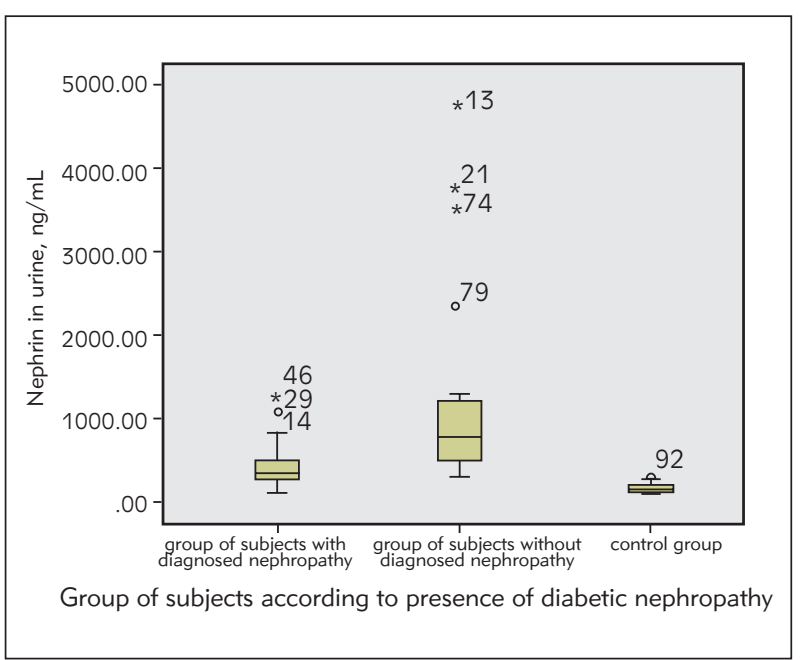

Figure 4 The concentration of urinary nephrin in selected groups of patients - with and without diagnosed DN.

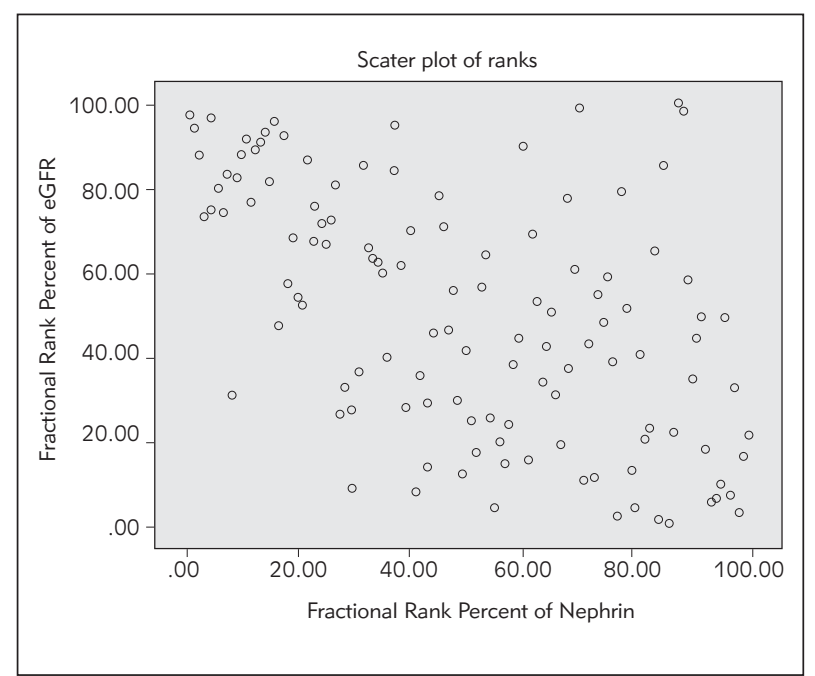

Figure 5 Spearman's correlation rank between urinary nephrin and eGFR.

without diagnosed diabetic nephropathy and healthy subjects. The results show that the level of urinary nephrin in both selected groups of patients with T2DM is statistically significantly higher compared to healthy subjects $(p<0.05)$. The results are shown in Figure 4.

\section{Correlation between urinary nephrin and eGFR}

We ordered correlation rank between the concentration of urinary nephrin and estimated glomerular filtration rate in all subjects with T2DM by Spearman's method. Correlation is negative and statistically significant (Spearman $r=-0.54, p<10^{-3}$ ).

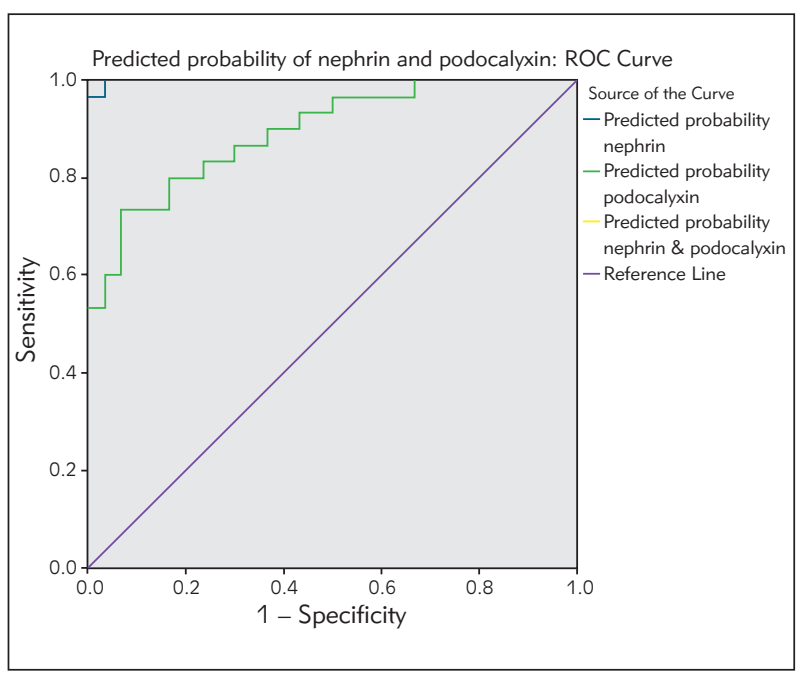

Figure $6 \mathrm{ROC}$ analysis of urinary nephrin.

\section{Non-parametric ROC analysis}

We used ROC analysis to assess the diagnostic efficiency of urinary nephrin in discrimination between patients with DN and healthy subjects. We performed binary logistic regression, and we found that nephrin has an accuracy of $96 \%$ as a discriminator between patients with DN and healthy subjects.

\section{Discussion}

Microalbuminuria was previously considered as a gold standard for early detection of DN. Body of evidence also indicates that microalbumin in urine is a nonspecific and nonsensitive marker for early detection of DN, it is elevated in other pathological conditions such as urinary tract infections, acute illness, cardiovascular diseases $(21,23)$. Presence of microalbumin in urine suggests damage of all three components of the glomerular filtration barrier (endothelium, glomerular basement membrane, and podocytes), and its diagnostic accuracy is limited by the fact that structural damage might precede microalbumin excretion (24). The presence of nephrin and other podocyte-specific proteins in urine indicate only damage of podocytes, independently of the other two components of the glomerular filtration barrier (16). Thus, it is thought that podocyte damage is present before the appearance of microalbuminuria and proteinuria, hence, podocyte proteins such as nephrin are considered as earlier and more specific markers for diagnosis of $D N$ compared to microalbuminuria.

In our study, we used the ELISA method for the quantification of urinary nephrin. We detected statistically significantly elevated concentrations of urinary nephrin in patients with T2DM compared to healthy subjects. It is particularly important that we found a statistically significant difference in the concentration of urinary nephrin in normoalbuminuric subjects with 
T2DM compared to healthy subjects. These results indicate that damage of podocytes is present in subjects with T2DM before the appearance of microalbuminuria. It is important to highlight that we found an elevated concentration of urinary nephrin in $82 \%$ of normoalbuminuric subjects. The percent of subjects with elevated urinary nephrin in the subgroup with microalbuminuria was $88 \%$, while in the subgroup with macroalbuminuria was $100 \%$. Our findings are similar to those published by Jim et al. (18) who detected that $54 \%$ of normoalbuminuric patients had increased nephrin and all (100\%) patients with macroalbuminuria and microalbuminuria had elevated nephrin.

The level of urinary nephrin correlated negatively with GFR, indicating that nephrinuria is a marker of disordered renal function. In the study of $\mathrm{Ng}$ DPK, the same correlation was found, although a different method for measurement of nephrin and GFR was used (25). A significant negative correlation between urinary nephrin and GFR was also found in the study of Jim et al. (18).

$\mathrm{ROC}$ analysis showed that nephrin has a total predicted probability of $96 \%$ in subjects with DN. This means high discriminatory power between healthy subjects and patients with DN; also this result means high sensitivity and specificity of nephrin as a urinary biomarker in early detection of DN. In the literature, we do not find data on the predicted probability of nephrin.

The limitations of the study are the small sample size and cross-sectional nature of the study, and we do not know if nephrinuria is part of a causal mechanism, or early nephrinuria will consistently predict

\section{References}

1. Ninomiya T, Perkovic V, de Galan BE et al. Albuminuria and kidney function independently predicts cardiovascular and renal outcomes in diabetes. J Am Soc Nephrol 2009; 20: 1813-21.

2. Go AS, Chertow GM, Fan D et al. Chronic Kidney Disease and the Risks of Death, Cardiovascular Events, and Hospitalization. N Engl J Med 2004; 351(13): 1296-305.

3. De Boer IH, Rue TC, Hall YN et al. Temporal trends in the prevalence of diabetic kidney disease in the United States. JAMA 2011; 305: 2532-9.

4. World Health Organization. (2016). Global report on diabetes. World Health Organization.

5. Rigalleau V, Lasseur C, Raffaitin C et al. Normoalbuminuric Renal-Insufficient Diabetic Patients. Diabetes Care 2007; 30: 2034-9.

6. Popovic D, Lalic K, Jotic A, Milicic T, Bogdanovic J, Đorđevic M, Stankovic S, Jeremic V, Lalic NM. The inflammatory and hemostatic cardiovascular risk markers subsequent DN. To answer these questions, we need to measure urinary nephrin prospectively in diabetic patients with normoalbuminuria. A large, prospective study is recommended to further assess the value of this marker in early detection of DN. If further research confirms that nephrinuria is a marker of preclinical DN, microalbumin as a previous gold standard will be replaced by urinary nephrin in routine laboratory practice as a marker for early detection of DN.

In conclusion, the results of this study indicate that urinary nephrin could be very important in early detection of DN, due to: high percent of normoalbuminuric subjects with elevated levels of urinary nephrin, statistically significant difference in the levels of urinary nephrin among subgroups of patients and healthy subjects and among selected groups of patients and healthy subjects, negative correlation between urinary nephrin concentration and GFR and high diagnostic sensitivity and specificity of nephrin in patients with DN. Furthermore, these results indicate that nephrin has greater diagnostic value in early detection of DN compared to microalbumin.

It could be concluded that urinary nephrin is an earlier marker than microalbumin and at the same time more specific and sensitive marker for detection of DN in an early stage.

\section{Acknowledgments. None declared.}

\section{Conflict of interest statement}

The authors stated that they have no conflicts of interest regarding the publication of this article.

during acute hyperglycemic crisis in type 1 and type 2 diabetes. J Med Biochem 2019; 38: 126-33.

7. Ünüvar S, Tanriverdi Z, Aslanhan H. Potential prognostic role of immune system activation marker neopterin in patients with type 2 diabetes. J Med Biochem 2018; 37: 465-9.

8. Nauta FL, Boertien WE, Bakker SJL et al. Glomerular and Tubular Damage Markers Are Elevated in Patients With Diabetes. Diabetes Care 2011; 34: 975-81.

9. Gatua WK, Makumi JN, Njagi EM et al. Evaluation of Urinary Tubular Enzymes as Screening Markers of Renal Dysfunction in Patients Suffering from Diabetes Mellitus. Asian J Med Sci 2011; 3(3): 84-90.

10. Kandasamy $Y$, Smith R, Lumbers ER et al. Nephrin - a biomarker of early glomerular injury. Biomark Res 2014; 2: 21.

11. Weil EJ, Lemley KV, Mason CC et al. Podocyte detachment and reduced glomerular capillary endothelial fen- 
estration promote kidney disease in type 2 diabetic nephropathy. Kidney Int 2012; 82(9): 1010-7.

12. Meyer TW, Bennett PH, Nelson RG. Podocyte number predicts long-term urinary albumin excretion in Pima Indians with Type II diabetes and microalbuminuria. Diabetologia 1999; 42: 1341-4.

13. White KE, Bilous RW, Marshall SM et al. Podocyte number in normotensive type 1 diabetic patients with albuminuria. Diabetes 2002; 51: 3083-9.

14. Asanuma K, Mundel P. The role of podocytes in glomerular pathobiology. Clin Exp Nephrol 2003; 7: 255-9.

15. Patari A, Forsblom C, Havana M et al. Nephrinuria in diabetic nephropathy of type 1 diabetes. Diabetes 2003; 52: 2969-74.

16. Nakamura T, Ushiyama C, Suzuki S et al. Urinary excretion of podocytes in patients with diabetic nephropathy. Nephrol Dial Transplant 2000;1 5: 1379-83.

17. Mogensen CE. Microalbuminuria as a predictor of clinical diabetic nephropathy. Kidney Int 1987: 31: 673-89.

18. Jim B, Ghanta M, Qipo A et al. Dysregulated Nephrin in Diabetic Nephropathy of Type 2 Diabetes: A Cross Sectional Study. PLoS ONE 2012; 7(5): e3604.
19. KDIGO. Chapter 1: Definition and classification of CKD. Kidney Int Suppl 2013; 3: 19.

20. Cockcroft, DW, Gault, MH. Prediction of creatinine clearance from serum creatinine. Nephron 1976; 16: 31-41.

21. Fiseha, T. Urinary biomarkers for early diabetic nephropathy in type 2 diabetic patients. Biomark Res 2015; 3: 16.

22. Bego T, Čaušević A, Dujić T, Malenica M, Velija-Asimi $Z$, Prnjavorac B, Marc J, Nekvindová J, Palička V, Semiz S. Association of fto gene variant (rs8050136) with type 2 diabetes and markers of obesity, glycaemic control and inflammation. J Med Biochem 2019; 38: 153-63.

23. Baldane S, Kendir IC, Kirac CO, Ipekci S, Tekin G, Unlu A, Kebapcilar L. Effects of glucose ingestion on serum fractalkine levels in healthy subjects and newly diagnosed type 2 diabetic patients. J Med Biochem 2018; 37: 373-8.

24. Khalid Al-Rubeaan, Khalid Siddiqui, Mohammed A et al. Assessment of the diagnostic value of different biomarkers in relation to various stages of diabetic nephropathy in type 2 diabetic patients. Scientific Reports 2017; 7(1) doi: 10.1038/s41598-017-02421-9.

25. Ng DPK, Tai B-C, Tan E et al. Nephrinuria associates with multiple renal traits in type 2 diabetes. Nephrol Dial Transpl 2010; 26: 2508-14. 